\title{
Osteoblast Differentiation and Bone Matrix Formation In Vivo and In Vitro
}

\author{
Harry C. Blair, MD, ,2 Quitterie C. Larrouture, MS, Yanan Li, MD, $\mathrm{PhD}^{3}$, Hang Lin, $\mathrm{PhD}^{4}$ \\ Donna Beer-Stoltz, PhD, Li Liu, MD, PhD,2 Rocky S. Tuan, PhD, Lisa J. Robinson, MD, \\ Paul H. Schlesinger, MD, $\mathrm{PhD}^{7}$, and Deborah J. Nelson, $\mathrm{PhD}^{8}$
}

We review the characteristics of osteoblast differentiation and bone matrix synthesis. Bone in air breathing vertebrates is a specialized tissue that developmentally replaces simpler solid tissues, usually cartilage. Bone is a living organ bounded by a layer of osteoblasts that, because of transport and compartmentalization requirements, produce bone matrix exclusively as an organized tight epithelium. With matrix growth, osteoblasts are reorganized and incorporated into the matrix as living cells, osteocytes, which communicate with each other and surface epithelium by cell processes within canaliculi in the matrix. The osteoblasts secrete the organic matrix, which are dense collagen layers that alternate parallel and orthogonal to the axis of stress loading. Into this matrix is deposited extremely dense hydroxyapatite-based mineral driven by both active and passive transport and $\mathrm{pH}$ control. As the matrix matures, hydroxyapatite microcrystals are organized into a sophisticated composite in the collagen layer by nucleation in the protein lattice. Recent studies on differentiating osteoblast precursors revealed a sophisticated proton export network driving mineralization, a gene expression program organized with the compartmentalization of the osteoblast epithelium that produces the mature bone matrix composite, despite varying serum calcium and phosphate. Key issues not well defined include how new osteoblasts are incorporated in the epithelial layer, replacing those incorporated in the accumulating matrix. Development of bone in vitro is the subject of numerous projects using various matrices and mesenchymal stem cell-derived preparations in bioreactors. These preparations reflect the structure of bone to variable extents, and include cells at many different stages of differentiation. Major challenges are production of bone matrix approaching the in vivo density and support for trabecular bone formation. In vitro differentiation is limited by the organization and density of osteoblasts and by endogenous and exogenous inhibitors.

Keywords: tight junction, $\mathrm{ClC}$ chloride proton exchangers, $N H E$ sodium-hydrogen exchangers, sodium hydrogen exchanger regulatory factor-1, BMP-2, sclerostin, bone morphogenetic proteins, activin/inhibin

\section{Introduction}

B ONE, IN THE AIR-BREATHING vertebrates, is a highly specialized tissue with many advanced features not found in bony fishes. ${ }^{1}$ During development, bone usually replaces solid and avascular mesenchymal tissue, mainly mineralized cartilage or fibrocartilage. These tissues are important, but separate topics, ${ }^{2}$ which will not further be considered.

A key concept is that bone is a living organ with cellular and structural components that have defined ontogeny and biochemical functions. Particularly, the structural component of living bone, the extracellular matrix, is separated from general extracellular fluid by a tight epithelial layer of osteoblasts. This principal is of highest importance, and it is often not appreciated. It is exemplified in rapidly fixed bone demonstrating its structure with minimal degeneration (see Fig. 1). Osteoblasts in the organized epithelioid structure secrete bone organic matrix, and remain as a tight epithelium to control the matrix environment for mineralization.

\footnotetext{
${ }^{1}$ Veteran's Affairs Medical Center, Pittsburgh, Pennsylvania.

${ }^{2}$ Department of Pathology, University of Pittsburgh, Pittsburgh, Pennsylvania.

${ }^{3}$ Department of Stomatology, Chinese PLA General Hospital, Beijing, China.

${ }^{4}$ Department of Orthopaedic Surgery, Center for Cellular and Molecular Engineering, University of Pittsburgh, Pittsburgh, Pennsylvania. Departments of ${ }^{5}$ Pathology and ${ }^{6}$ Microbiology, Immunology \& Cell Biology, West Virginia University School of Medicine, Morgantown, West Virginia.

${ }^{7}$ Department of Cell Biology, Washington University, Saint Louis, Missouri.

${ }^{8}$ Department of Neurobiology, Pharmacology \& Physiology, University of Chicago, Chicago, Illinois.
} 


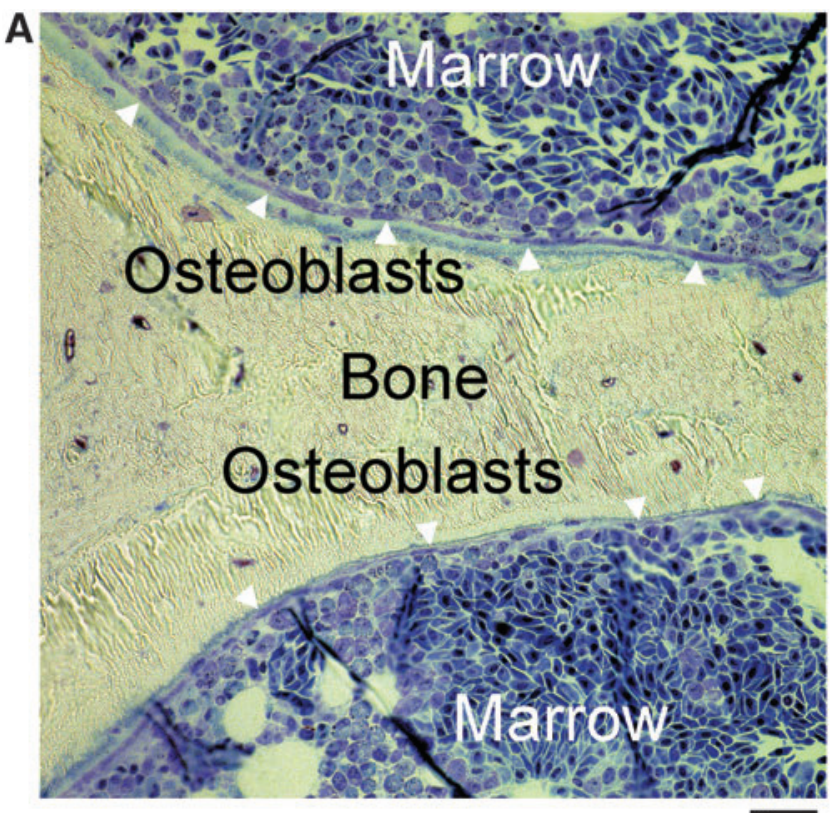

$\overline{20 \mu m}$

D

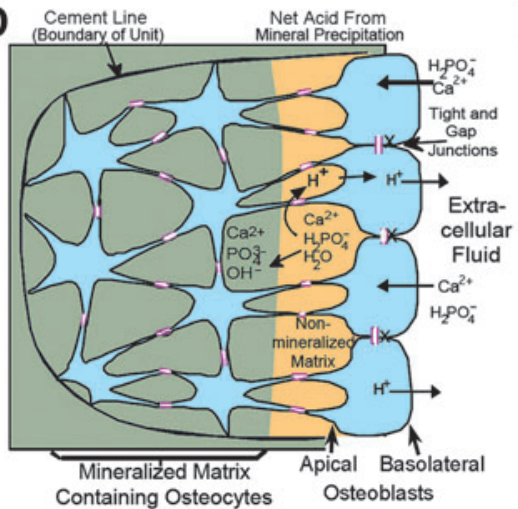

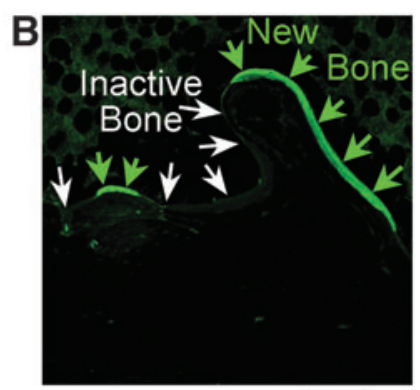

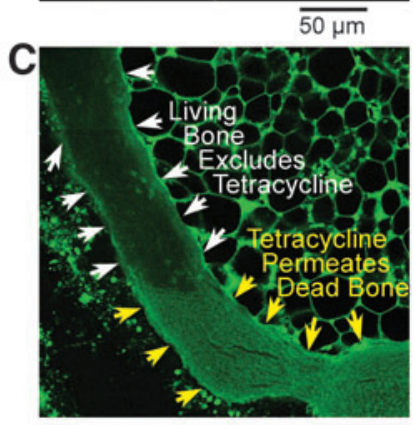

$\overline{50 \mu \mathrm{m}}$

$\mathbf{F}$

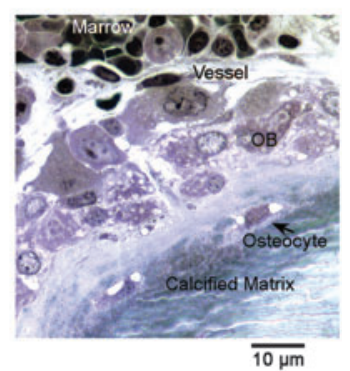

FIG. 1. Characteristics of bone with special fixation and labeling protocols. (A) A low-power view from a preparation previously published, ${ }^{1}$ showing the continuity of bone-lining osteoblasts (arrows) and well-preserved marrow; dark regions are developing red blood cells. Briefly, this is a $1 \mu \mathrm{m}$ section in epoxy, surface stained with methylene blue. For very-highquality fixation, ${ }^{2} \mathrm{~mm}$ fragments of freshly killed avian femoral trabecular bone immediately after sacrifice by $\mathrm{CO}_{2}$ inhalation, were dropped into cold $2 \%$ glutaraldehyde and $1 \%$ paraformaldehyde. The animal was prepared with a low calcium diet to soften the skeleton. ${ }^{45}$ (B) A low-power laser scanning confocal fluorescent photograph of the bone surface of rabbit femur trabecular bone in an animal given tetracycline before sacrifice. Bone formation is labeled with tetracycline (green arrows); other sites are unlabeled (white arrows). Thus, bone-lining cells are impermeable; during bone formation, basic calciumbinding material, including calcein or tetracycline, is incorporated in hydroxyapatite. An unpublished image from the study. ${ }^{16}$ (C) A laser scanning confocal image from the study shown in (B), but in an animal treated for 4 weeks with high-dose corticosteroids, inducing osteonecrosis. ${ }^{16}$ In the necrotic region, there is diffuse tetracycline uptake (green arrows), but not in living bone (white arrows). Thus, when bone dies, it becomes permeable to low-MW substances, including hydroxyapatitebinding molecules. Diffuse-nonspecific uptake is quantitatively much less than tetracycline transport during bone formation (B); bright cells outside of the bone are marrow autofluorescence. (D) The basic features of osteoblast organization, an osteon. Its structure is delineated by an impermeable cement line (left) and by surface osteoblasts connected by gap and tight junctions. During bone mineral transport, the process of mineral deposition produces acid. Exclusively during mineral transport, osteoblasts also transport hydroxyapatite-binding fluorescent molecules. (E) A high-power light photograph of a preparation similar to (A), but fixed in the hypertonic medium. A tangential section of the bone surface reveals the dense tight junctions between osteoblasts as spiky intercellular connections (arrows). (F) Bone is a highly vascular organ: a high-power light photograph of active bone formation from the preparation shown in (A). Note the capillary (vessel) adjacent to the bone and the continuous layer of osteoblasts adjacent to nonmineralized bone, osteoid, with osteocytes incorporated in the matrix.

With continuing growth, some osteoblasts are incorporated into the matrix as living cells, osteocytes, which are a permanent part of the living organ. New osteoblasts are recruited in a coordinated manner from mesenchymal stem cells and committed osteoblast precursors to maintain the continuous epithelial layer over actively forming bone. These cells become osteocytes after incorporation into bone matrix and communicate with each other and surface layer osteoblasts through cell processes that run within canaliculi that permeate the matrix. 
The organic matrix of bone is very dense, highly crosslinked, type I collagen. It also contains quantitatively small amounts of accessory proteins, including osteopontin and osteocalcin, which are important in coordinating the organic matrix and bone mineral. ${ }^{3}$ Collagen in mature bone is in dense parallel layers that alternate in orientation, parallel to and orthogonal to the axis of load, at $\sim 2 \mu \mathrm{m}$ intervals. Into this collagen matrix is deposited hydroxyapatite-based microcrystals. Crystal nucleation is driven by two phases of coupled transport, which removes protons and condenses the mineral into the very dense hydroxyapatite microcrystals required to form the strong and dense bone composite. Adjacent to cells and cell processes, the matrix is not well organized, reflecting the reorganization and condensation guided by accessory proteins from initial nucleation, resulting in dense lamellar structure of mature bone. ${ }^{4}$

Recent advances clarify the mechanism driving critical initial mineralization. It requires two-phase removal of acid evolved during hydroxyapatite nucleation by the osteoblast epithelium enclosing the mineralization compartment. This process allows mineral formation to proceed to completion at varying serum calcium and phosphate..$^{5}$ Once deposited, the mineral undergoes maturation from amorphous calcium phosphate to hydroxyapatite, with important changes in mineral orientation and organization. This surprisingly slow and complex process depends critically on $\mathrm{pH}^{6}$

Poorly characterized processes include how new osteoblasts are incorporated into growing bone, a process that is, at least in part, regulated by matrix vesicles, ${ }^{7}$ and the effects of endogenous and cell-produced growth and differentiation factors (GDFs) in vitro and in vivo. Key GDFs were established long ago. ${ }^{8}$ The GDFs involved in bone development also regulate other organs. ${ }^{8}$ What drives bone differentiation is when and where GDFs occur in relation to the receptive stage of the target cell. An important misconception is that individual cytokines, including bone morphogenetic protein2 (BMP-2), are specific to bone.

Last, we will consider the development of bone in vitro. This is the subject of numerous projects that use either tissue culture plates or a variety of matrices and mesenchymal stem cell-derived preparations in bioreactors. These preparations reflect the structure of bone to variable extents and include cells at many different stages of differentiation. Difficulties include production of trabecular bone and quantitative production of bone matrix approaching its natural density. Misconceptions associated with tissue culture bone include " $2 \mathrm{D}$ cultures" making bone; bone developing on tissue culture plates occurs where dense, typically nodular, aggregates of osteoblasts can secrete matrix (vide infra). Cultures without artificial scaffolds are called 2D, but really are not. Challenges include that bone production in vitro is self-limited. The reasons are complex; among these, sclerostin is produced in large concentrations by osteoblast cultures ${ }^{9}$ and glucocorticoids inhibit osteoblast proliferation. ${ }^{10}$ This and related issues may be addressed by better and more detailed tissue engineering approaches.

\section{Fundamental Bone Organization and Cell Biology}

Osteoblasts, when forming bone, are cuboidal cells with large amounts of rough endoplasmic reticulum and mitochondria. ${ }^{11}$ In older work using osteoblasts in cell culture media, the high oxidative activity of osteoblasts was identified. However, in vivo, fatty acids are a key source for bone synthesis ${ }^{12}$; elimination of the major HDL component causes severe osteoporosis. ${ }^{13}$ Osteoblasts that are not synthesizing bone are low-columnar cells, but still form a continuous membrane (Fig. 1A).

Table 1 shows important osteoblast RNA expression by functional class. To allow comparison of data by relative expression, we show hybridization levels and $p$-values from two of our human osteoblast cRNA gene screens, with references to literature reports that reported similar expression of each target in other cell preparations. Since many workers have performed studies of this type, data in many references overlap and we regret that it is not possible to reference all studies.

The synthetic bone matrix side of the osteoblast is its apical surface. The apical surface is, among other things, the site of massive membrane-bound alkaline phosphatase. ${ }^{37}$ Bone alkaline phosphatase is a good indicator of bone synthesis. ${ }^{38}$ Alkaline phosphatase is necessary to supply phosphate for bone mineral, but it alone is not sufficient for mineralization, further discussed below. At the apical surface, osteoblasts secrete large amounts of type I collagen and smaller amounts of matrix organizing proteins, including osteocalcin and osteopontin. ${ }^{39}$ Osteocalcin is transcribed, for practical purposes, only for the organic matrix; so it is a useful indicator of osteoblast synthetic activity; it is also a signaling molecule. ${ }^{19}$ The organic bone matrix is a hydrated protein matrix, called osteoid. The side of the osteoblast oriented toward the bone marrow or the periosteum is its basolateral surface.

Bone formation begins at a cement line, a thin layer of mineral through which no cell processes pass, generally laid down at a site cleared by osteoclasts and then immediately occupied by an epithelioid layer of osteoblasts. Little is known about the composition of the cement line, although it may have a different protein-mineral mixture than in bone. ${ }^{40}$ Gap junction-connected groups of osteoblasts making bone, at a cement line, and extending several layers of cells to the bone surface is called an osteon. All cells in an osteon are connected by gap junctions centered on connexin $43 .{ }^{41}$ Processes of osteoblasts and osteocytes overlap in the canaliculi, so the surface area of the cellular connections is much larger than suggested by the narrowness of the canaliculi.

The osteocytes, osteoblasts buried in bone matrix, live as long as the bone lives and are an essential feature of bone. Osteocytes retain connections with the surface layer of osteoblasts. ${ }^{42,43}$ In devitalized bone, the canaliculi formerly occupied by processes of osteocytes and osteoblasts can be filled with dye, classically India ink, to visualize the system, which is still useful in teaching.

Bone is a living organ maintained by living cells, osteoblasts and osteoclasts. The alkaline nature of bone formation, with the defining ectoenzyme alkaline phosphatase and, in contrast, the acidic environment of bone degradation by osteoclasts, containing acid phosphatase, were appreciated 60 years ago. ${ }^{44}$ Maintaining these $\mathrm{pH}$ gradients in juxtaposed compartments requires physical isolation (Fig. 1A) and directed transport between high or low $\mathrm{pH}$ compartments and the extracellular fluid.

More specifically, $\mathrm{pH}$ gradients require tight control of access to the bone surface, including a barrier to diffusion. This is demonstrable in vivo using low-molecular-weight (MW) hydroxyapatite-binding fluorescent ions, including the fluorescent compounds tetracycline, calcein, and congeners. These are 
Table 1. Expression of Selected mRNAs in Human Osteoblast Cultures: Data Using AfFymetrix cRNA Hybridization as Described ${ }^{14}$

\begin{tabular}{|c|c|c|c|c|}
\hline Gene & Description & Hybridization & $\mathrm{p}$ & Consistent reports \\
\hline \multicolumn{5}{|c|}{$\begin{array}{l}\text { Conversion of cartilage to bone and regulators of osteoclast formation. In osteoblasts, VEGF, RANKL, and osteoprotegerin } \\
\text { all are upregulated by adrenocorticotropic hormone }(A C T H){ }^{15} \text { In high-dose glucocorticoid treatment, ACTH is } \\
\text { suppressed and osteonecrosis may occur (see Fig. } 1 B, C) .{ }^{16}\end{array}$} \\
\hline$V E G F$ & Vascular endothelial growth factor-1 & 830 & 0.0007 & \multirow[b]{3}{*}{$15,17,18$} \\
\hline TNFRSF11B & Osteoprotegerin & 770 & 0.0002 & \\
\hline TNFSF11 & Receptor activator of nuclear factor $-\kappa B$ & 190 & 0.01 & \\
\hline
\end{tabular}

Bone structural proteins. Osteoblasts make more type 1 collagen than any other cell, by a wide margin. Alkaline phosphatase is an ectoenzyme, highly expressed in active osteoblasts at the apical membrane. Osteocalcin occurs only in bone and may also function in signaling. ${ }^{19}$

\begin{tabular}{llrl}
\hline COL1A1 & Type 1 collagen, $\alpha-1$ chain & 21,300 & 0.0002 \\
ALPL & Alkaline phosphatase & 2800 & 0.0002 \\
BGLAP & Osteocalcin & 1200 & 0.0002 \\
\hline Secretory osteoblast transport and regulation proteins. Sodium-hydrogen exchangers 1 and 6 are expressed in basolateral \\
surface active \\
surface active osteoblasts ${ }^{21}$; the sodium-hydrogen exchanger regulatory factor-1 is confined to the basolateral \\
highly expressed in apical surfaces of active osteoblasts; CLC5 is quantitatively suppressed when CLC3 is present. \\
\hline SLC9A6 \\
SLC9A3R1 & Sodium-hydrogen exchanger-6 & 1300 & 0.0002 \\
CLCN3 & Na/H exchanger regulatory factor-1 & 540 & 0.01 \\
CLCN5 & Chloride proton antiport-3 & 2000 & 0.0002 \\
\hline
\end{tabular}

Characteristic of osteocytes. Sclerostin inhibits bone formation by binding LRP5/6 and may be a factor limiting the success of bioreactor results. ${ }^{24,25}$

\begin{tabular}{|c|c|c|c|c|}
\hline SOST & Sclerostin & 3000 & 0.0002 & 9 \\
\hline \multicolumn{5}{|c|}{$\begin{array}{l}\text { Bone morphogenetic protein superfamily. Comment: Expressed on cell surfaces; induce differentiation. Transforming } \\
\text { growth factors, BMPs, and activin/inhibin are all dimers. TGF } \beta \text { is not specific for cartilage; it is widely expressed. }{ }^{26} \text { Type } \\
1 \text { and type } 2 \text { receptors are required for signaling. Many BMPs signal through the same receptors; none are bone specific, } \\
\text { including BMP-2. }{ }^{27-30} \text { Endogenous BMP expression is a major reason added BMPs are often ineffective in tissue } \\
\text { cultures. }\end{array}$} \\
\hline$T G F B 1$ & Transforming growth factor $\beta 1$ & 6500 & 0.0002 & \\
\hline$B M P-1$ & Bone morphogenetic protein-1 & 3800 & 0.0002 & \\
\hline$B M P-2$ & Bone morphogenetic protein-2 & 600 & 0.01 & \\
\hline$B M P-10$ & Bone morphogenetic protein-10 & 180 & 0.05 & \\
\hline INHBA & Inhibin $\beta A$, component of activin and inhibin & 2100 & 0.0002 & \\
\hline INHA & Inhibin $\alpha$ chain & 200 & 0.02 & \\
\hline$I N H B C$ & Inhibin $\beta \mathrm{C}$ chain & 430 & 0.0002 & \\
\hline TGFBR1 & Transforming growth factor $\beta$ receptor- 1 & 610 & 0.01 & \\
\hline TGFBR2 & Transforming growth factor $\beta$ receptor- 2 & 740 & 0.0007 & \\
\hline$B M P R 1 A$ & BMP receptor type 1 isoform A & 1600 & 0.0002 & \\
\hline$B M P R 2$ & BMP receptor type 2 & 460 & 0.01 & \\
\hline$A C V R 1$ & Type 1 activin receptor, related to BMPR 1 & 5100 & 0.0002 & \multirow[b]{2}{*}{$18,31-36$} \\
\hline$A C V R 2$ & Type 2 activin receptor, related to BMPR2 & 710 & 0.01 & \\
\hline
\end{tabular}

Hybridization averages analysis of two human osteoblast cultures at 2 weeks in a bone differentiation medium. Background is $\sim 100 \mathrm{U}$. $n=18$, rounded to two significant places; exact $p$-values. The last column cites studies reporting consistent data, mainly for human cells in an osteoblast medium, in a few cases for mouse mesenchymal stem cells (MSC).

strictly excluded from bone, with two important exceptions: during bone formation, when large amounts of calcium and phosphate are transported across secretory osteoblasts, calcium binding fluorescent molecules are cotransported (Fig. 1B). This was discovered by Harold M. Frost in the late 1950s. In addition to showing that bone in general is impermeable, this discovery provided a tool for measuring bone formation. ${ }^{46}$ The calcium binding fluorescent dyes or phosphate analogs, including bi- sphosphonates, are bound to, and included in, the mineral matrix during mineral accumulation, as demonstrated by far red fluorescent bisphosphonates. ${ }^{47}$

The second exception is that dead bone is nonspecifically permeable. ${ }^{16}$ In the example of regional osteonecrosis, bone becomes immediately and nonspecifically permeable to tetracycline. In dead bone, there is free diffusion through the matrix and diffuse dye binding (Fig. 1C). In contrast, during mineral 
transport, hydroxyapatite binding dyes are vectorially transported at high concentrations in new mineral (Fig. 1B). Figure $1 \mathrm{~B}$ and $\mathrm{C}$ are unpublished frames from our study. ${ }^{16} \mathrm{An}$ osteon with tight and gap junctions representing the active process of bone synthesis is diagrammed in Figure 1D.

\section{Active Transport Supports Rapid and Quantitative Vectorial Mineralization}

The mechanism by which the mineralization is driven rapidly to completion is only now becoming clear. The key to understanding this is centered on equation of mineral formation:

$$
\begin{array}{r}
6 \mathrm{HPO}_{4}{ }^{2-}+2 \mathrm{H}_{2} \mathrm{O}+10 \mathrm{Ca}^{2+} \leftrightarrow \mathrm{Ca}_{10}\left(\mathrm{PO}_{4}\right)_{6}(\mathrm{OH})_{2}+8 \mathrm{H}^{+} \\
\text {Equation } 1
\end{array}
$$

This simple equation ignores intermediates, calcium phosphates, which later mature into hydroxyapatite. Furthermore, many substitutions occur in intermediates, including carbonates. Nevertheless, the equation is key to understanding the thermodynamics of bone formation, including how very dense mineral can be accumulated, in a vectorial manner, at a constant rapid rate under a wide variety of serum mineral and $\mathrm{pH}$ conditions. To drive bone mineralization the export of acid from the forming matrix is critical. This requires isolation of the matrix from general extracellular fluid, as we have observed and discussed elsewhere (above - "Exclusion of Low-MW Ions", and following - "Exceptions That Require Additional Transporters." Other aspects of mineralization, including important accessory proteins that support crystal nucleation, which is important for ultimate bone strength, ${ }^{3}$ are discussed below in Matrix Maturation and $\mathrm{pH}$ section.

Chemists interested in hydroxyapatite deposition have long been aware that this requires removal of protons for mineral precipitation, ${ }^{48}$ just as addition of protons is essential for recovery of ionic phosphate and calcium during bone resorption. ${ }^{49}$ It was difficult to explore transport mechanisms in the pregenomic world, but studies in the $1980 \mathrm{~s}$ using $\mathrm{pH}$ measurements, while manipulating extracellular ions, showed high-capacity sodium-hydrogen exchange, removing acid from osteoblasts. ${ }^{50,51}$

A classic view was that tissues mineralize in open systems; this is indeed the case in dystrophic calcification or calcium phosphate crystals in vitro, including in bone cell cultures; this is not bone, and distinguishing dye binding of calcium salts from bone is an important problem. ${ }^{52}$ In cartilage, which has no boundary epithelium, acid can diffuse away and mineral can form solely supported by alkaline phosphatase; in the alkaline phosphatase knockout, mineralized cartilage is absent. ${ }^{53}$

In a closed space, such as the isolated matrix lined by impervious osteoblasts, removing the acid will drive mineral formation strongly to completion, very rapid formation of extremely dense mineral possible. This is what happens in true bone. Figure 2A shows our model of the canonical mineralization process. The model centers on $\mathrm{H}^{+}$removal to drive mineral precipitation to completion (Equation 1); since bone is a tight epithelium, there are also passive calcium transporters and neutral phosphate transporter-1 (NPT1) that supply the ions for mineral deposition. ${ }^{23,54}$

Transporters in the epithelioid osteoblasts mediate acid uptake from bone matrix at the osteoblast apical membranes and acid extrusion at the basolateral membranes. On their basolateral membranes, osteoblasts express sodium-hydrogen exchangers 1 and 6 (Fig. 2B). ${ }^{21}$ On the apical membranes, $\mathrm{Cl}^{-} / \mathrm{H}^{+}$exchangers move acid into osteoblasts (Fig. 2C). ${ }^{5}$ This process and osteoblast phosphate transport are regulated by the sodium-hydrogen exchanger regulatory factor- $1 .^{22}$

It is established that osteoblast apical membrane phosphatases, particularly alkaline phosphatase, also to some extent PHOSPHO1, and in a complex and sometimes inhibitory manner ENPP1, ${ }^{55,56}$ regulate phosphate production that is essential for mineralization. On the other hand, when $\mathrm{ClC} 3$ and 5 are absent, there is normal alkaline phosphatase activity, but no mineral production (Fig. 2D). ${ }^{5}$ The phosphate supply is normal, but the osteoblasts cannot make the gradient that drives mineral transport to completion (Equation 1). Important processes are not accounted by this model: Osteoid is a dense collagen hydrogel; when osteoid is mineralized, the water is eliminated. Clearly, water transport vectorially out of new bone is necessary; tissue arrays suggest that osteoblasts express aquaporins. ${ }^{57}$ Ion transporters that balance the $\mathrm{ClC}$ and NHE exchangers are also not known, although direct measurement in osteosarcoma cells revealed outwardly rectifying $\mathrm{K}^{+}$channels, which might drive $\mathrm{ClC}$ exchangers. ${ }^{58}$ Other ion transporters are required, and remain to be studied, at the basolateral surface, an outward pump of net sodium, and at the apical surface, reuptake of chloride.

\section{Exclusion of Low-MW lons, and Exceptions That Require Additional Transporters}

To exclude low-MW charged molecules from the bone matrix, tight junctions between cells are required. These are demonstrated in osteoblasts fixed in a hypotonic medium (Fig. 1E). Numerous studies have consistently reported these at cellular, ultrastructural, and biochemical levels. ${ }^{59-63}$

This implies that the local uptake of calcium binding ions and fluorescent probes during bone synthesis (Fig. 1B, C) cannot be by diffusion. The bone mineral components, phosphate and calcium, are transported by specific membrane channels such as the NPT $2,{ }^{23}$ which do not cotransport hydroxyapatite binding molecules. These would not be transported as hydroxyapatite complexes, but rather bind to hydroxyapatite with high affinity after their transport. In this regard, osteoblasts strongly express SLC21 and SLC22 anion and cation transporters, ${ }^{64}$ and $\mathrm{ABCC} 1$ multidrug exporters. ${ }^{65}$ Our whole-exome cRNA screens in nontransformed human osteoblasts (not illustrated) showed high expression of SLC21/ 22 and $\mathrm{ABCC} 1$ as reported in transformed osteoblasts. ${ }^{64,65}$ No direct experimental evidence of dye transporters is reported.

\section{Coordination of Bone Development and Maturation}

Bone is highly vascular with a network of capillaries adjacent to active bone formation (Fig. 1F). This is important to support the demands of bone synthesis for collagen production and mineral transport, and is subject osteonecrosis during stress that reduces its vascular supply. The peritrabecular capillaries are delicate and usually lost in routinely fixed tissue. There are interesting endocrinological support issues; synthetic osteoblasts make large amounts of vascular endothelial growth factor (VEGF) (Table 1), which is, in large part, supported by adrenocorticotropic hormone. When adrenocorticotropic homone (ACTH) is suppressed by large quantities of glucocorticoids, this 

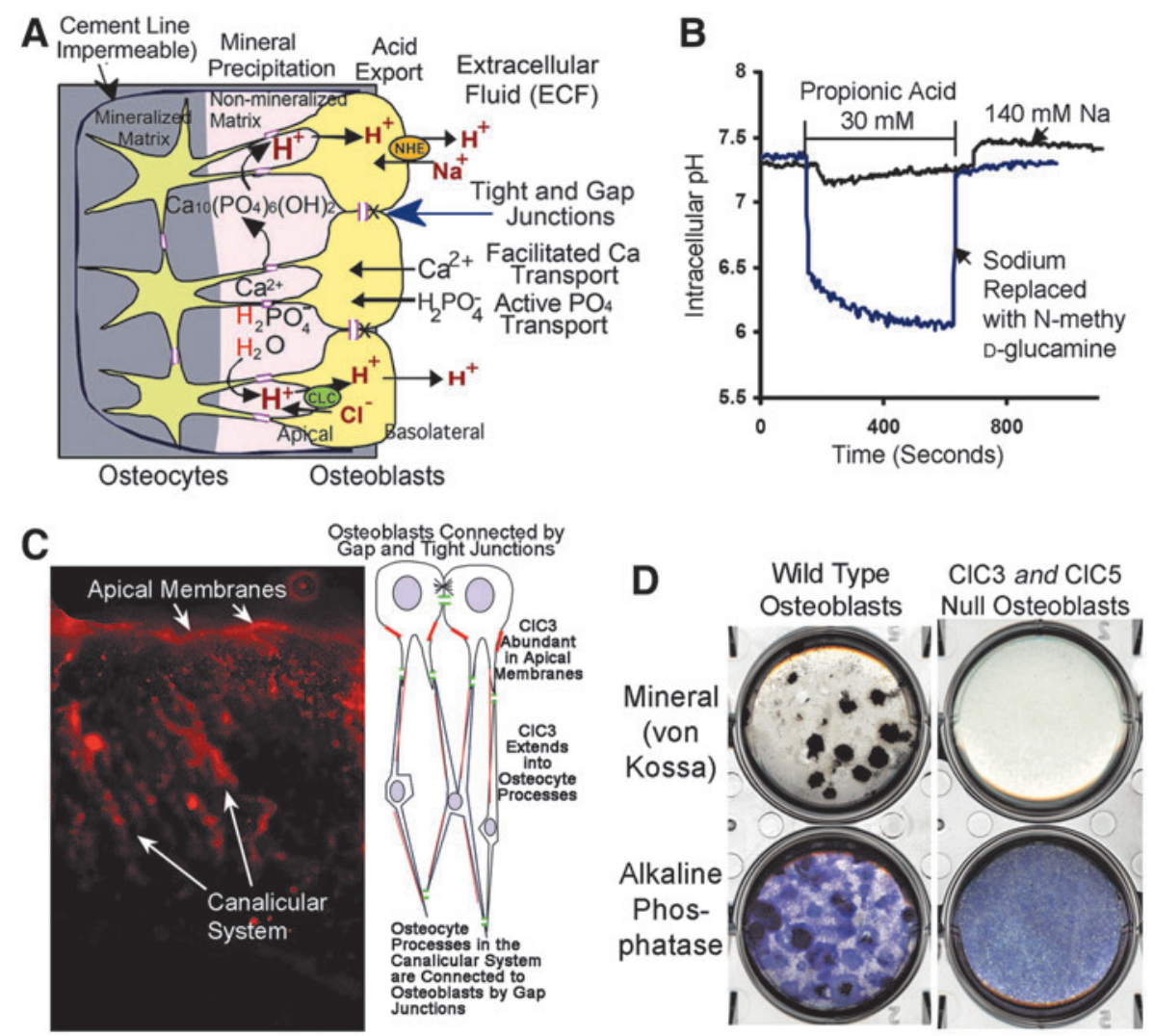

FIG. 2. Major mechanisms of osteoblast acid transport that support complete conversion of phosphate and calcium to hydroxyapatite. Osteoblasts actively transport phosphate, ${ }^{23}$ which is converted from pyrophosphate or nucleotide phosphates by alkaline phosphatase and other phosphatases. Hydroxyapatite is organized, in part, by accessory proteins, but the process of crystallization generates massive amounts of acid. Removal of this acid has the effect of driving precipitation to completion, regardless of extracellular conditions. (A) Key mechanisms driving bone mineral formation to completion include uptake of acid by $\mathrm{ClC}$ exchangers at the apical membrane, and acid transcytosis with elimination by NHE exchangers at the basolateral membrane. Modified from, ${ }^{5}$ with permission. (B) Demonstration of massive sodium-hydrogen exchange capacity. Osteoblasts exposed to a large acid load, $30 \mathrm{mM}$ propionic acid, a membrane-permeant organic acid, maintain their internal $\mathrm{pH}$ at neutral in the presence of sodium. In the absence of sodium, the cells acidify dramatically. The acid resistance is due to two highly expressed sodium-hydrogen exchangers on the basolateral membranes of osteoblasts. Modified from Liu et al., ${ }^{21}$ with permission. (C) Human osteoblasts express the chloride-hydrogen exchanger ClC3 at high levels. Fluorescent antibody labeling of $\mathrm{ClC} 3$ in bone cortex is shown; the osteoblastic surface is at top and there is very high expression of $\mathrm{ClC} 3$ in the apical membranes. The diagram at right shows cells and processes, the labeling of which is demonstrated in the photograph. $\mathrm{ClC} 3$ occurs also in the canalicular system. ClC3-knockout controls were unlabeled (not shown). If $\mathrm{ClC} 3$ is knocked out, $\mathrm{ClC} 5$ expression increases and has the same pattern of expression (not shown). Modified from Larrouture et al., ${ }^{5}$ with permission. (D) Bone formation by wild-type and ClC3/5-null osteoblasts. Wild-type murine osteoblasts make bone in characteristic nodules with very strong mineral deposition or alkaline phosphatase activity (left panels). Osteoblasts express two $\mathrm{ClCs}, 3$ and 5, on their apical membranes. When $\mathrm{ClC} 3$ is knocked out, there is a minor bone phenotype (not shown). ${ }^{5}$ When both $\mathrm{ClC} 3$ and 5 are eliminated, there is no mineralization (top right). The lack of ClC expression does not affect alkaline phosphatase expression (bottom). Two centimeter diameter cultures, in six-well plates, of murine osteoblasts at 14 days in the osteoblast medium without cortisol. Modified from Larrouture et al., ${ }^{5}$ with permission.

causes osteonecrosis affecting regions of the skeleton that have active remodeling, such as the femoral head. ${ }^{15,16}$

\section{Matrix vesicles}

Bone synthesis is characterized by massive numbers of membrane vesicles shed at the apical surface of synthetic osteoblasts (not illustrated). These vesicles may have a number of functions, including cellular communication ${ }^{66}$ and in extending cell membrane surface to support mineralization. ${ }^{67} \mathrm{~A}$ widely held view is that matrix vesicles are important in hydroxyapatite crystal nucleation. ${ }^{68}$ While important features of bone, these vesicles are not the single force that drives dense mineral accumulation to completion. They provide no means for the elimination of acid extracted from the maturing mineral (Equation 1 and Fig. 2).

\section{Matrix maturation and $\mathrm{pH}$}

Although the overall process of transport for dense mineral accumulation can be put simply (Equation 1), the process also includes intermediate steps and is coordinated with accessory proteins and collagen in a maturation process, 3,4 where fully mature matrix may not be complete for days. This process involves maturation of calcium phosphates at nucleation sites into stable hydroxyapatite crystals and 
association of hydroxyapatite crystals with binding sites on collagen. Physical chemistry provides a useful further view of this: the presence of repeating charge alignment on collagen suggested that a nucleation lattice might be present. $^{69-71}$ However, it has not been possible experimentally to demonstrate nucleation sites on the nanometer scale. Recent simulation studies suggested that a threedimensional (3D) nucleation site could be identified. ${ }^{72} \mathrm{~A}$ particularly interesting aspect of mineralization of intrafibrillar collagen is that it only occurs experimentally when the $\mathrm{pH}$ is held at mildly alkaline levels. ${ }^{73}$ This is consistent with disruption of osteoclast inward acidification of the bone surface disrupting solubilization of bone mineral, ${ }^{74}$ and disruption of osteoblast outward proton transport preventing dense mineral deposition (Fig. 2). ${ }^{5}$

\section{Key Cytokines, GDFs, for Osteoblast Differentiation}

It is impractical to review all the signals that affect osteoblast formation and activity; key classes are presented. Some key GDFs for bone are included in Table 1.

\section{Systemic hormones}

Many systemic hormones function in bone, including pituitary hormones, including ACTH, follicle stimulating hormone, and thyroid stimulating hormone, ${ }^{14,15,75}$ once thought to function only by steroid production in endocrine organs. The steroid hormone family, particularly cortisol, ${ }^{76}$ sex steroids, ${ }^{77}$ and thyroxin (not a steroid, but signaling in the same manner $)^{78}$ are important. Cortisol does not stimulate bone matrix synthesis, but it can stimulate osteoblast differentiation, discussed below. Both parathyroid hormone (PTH) and PTHrp are important signals regulating osteoblasts, ${ }^{79}$ including regulation of proteins that coordinate bone formation and resorption (Table 1). The PTH receptor 1 is a G-protein-coupled receptor, one of several, including the calcium-sensing receptor and Wnt receptors that regulate osteoblasts. ${ }^{79}$

\section{Fundamental regulators of bone development}

VEGF and angiogenic hormone receptors are required for bone formation. ${ }^{80,81} \mathrm{VEGF}$ is required for conversion of cartilage to bone and remains important in maintaining bone viability during bone synthesis. ${ }^{15,81}$

Three classes of (usually) cell surface-or matrix-bound GDFs have profound effects on osteoblast differentiation, the transforming growth factor $\beta$ (TGF $\beta$ ) superfamily (including BMPs and GDFs), the FGF family, and the TNF family. Additional regulators of differentiation important in sites of bone growth and regulation of bone mass include Indian hedgehog, Wnts, and sclerostin. ${ }^{82,83}$

The TGF $\beta$ superfamily has many proteins that signal through a few receptors (Table 1). Its many promoters contain a large part of the information driving skeletal modeling and are important in repair and regeneration. ${ }^{84} \mathrm{~A}$ dramatic example is the focal expression of GDF5 (a BMP) at sites where digits separate in the embryo. ${ }^{85}$ Signals of the TGF $\beta$ superfamily, which includes BMPs, activin, GDFs, and TGF $\beta$, are required for bone formation, including the cartilage formation that usually precedes bone formation. BMP-2 or one of its cosignaling BMPs is a requirement for bone formation. A common misconception is that a specific
BMP is selective for osteoblast differentiation. Particularly, BMP-2 is not specific for osteoblast differentiation; its presence alone will not produce bone. BMP-2 is involved in pancreas/liver fate assignment in organogenesis. ${ }^{27}$ In epidermal regeneration, BMP-2 is an essential signal, ${ }^{28}$ and BMP-2 regulates a variety of other events in organogenesis. ${ }^{29}$ Furthermore, adding BMP-2 to osteoblast cultures usually has little effect, reflecting that differentiating MSCs intrinsically make large quantities of cell membrane-bound BMPs, including BMP-2 (Table 1). Activin and BMP receptors can substitute for one another. ${ }^{29,30}$ BMP receptors are of two types, with type 1 and type 2 receptors binding to a dimeric BMP. The type 2 activin and BMP receptors, which have serine/threonine kinase activity, are regulated by formation of the complexes. While different BMPs are expressed at specific times and places for differentiation, several of them can produce the same effect by the same receptors. What is essential is that signals and receptors occur at the proper time and place, with signaling generally highly localized, ${ }^{85}$ with BMPs in vivo being membrane tethered. Indeed, scavenger receptors eliminate BMPs that might escape their presenting cell, such as noggin, absence of which prevents normal separation of individual bones. ${ }^{86,87}$

FGF family signals, again with redundant cytokines signaling by fewer receptors, regulate bone formation, particularly being important in cartilaginous precursors, ${ }^{88}$ at sites adjacent to epithelium, and remain active in osteoblast differentiation. ${ }^{89}$ FGFs are usually heparin bound; two or more molecules are required to activate dimeric receptors. ${ }^{90}$ FGF23 is a specialized signal produced by osteocytes that downregulates phosphate reabsorption in the kidney. ${ }^{91}$

TNF family signals prominently include RANKL produced by osteoblasts, which regulate osteoclast differentiation, and osteoprotegerin, a decoy receptor that binds RANKL, which limits RANKL signaling (Table 1), these regulated by $\mathrm{PTH}$ and other signals. ${ }^{92}$ Many additional TNFs and receptors are present on osteoblasts and have specialized regulatory functions. ${ }^{93,94}$

\section{Bone Formation In Vitro}

\section{Two dimensional and $3 D$ cultures}

Mesenchymal stem cells or committed osteoblast cultures are usually called "2D" when cells are plated without an artificial matrix support, which, if used, is typically a hydrogel, and in which case, the cultures are termed "3D." These terms are, at least in part, misleading. There is no such thing as $2 \mathrm{D}$ bone; individual osteoblasts cannot make bone and when bone forms in osteons, it always has depth. Dense bone formed in vitro in tissue culture plates without artificial matrix occurs usually in nodular form, as we showed in the cell cultures used for demonstration of sodium-hydrogen exchange in human osteoblasts. ${ }^{21}$ Similar examples are shown in Figure 3A and B, with von Kossa stain or alkaline phosphatase activity demonstrated. Alkaline phosphatase activity is extremely high in areas of extracellular matrix mineralization, and generally appears nearly black by $\alpha$-naphthol phosphate/Fast Blue RR labeling of phosphatase activity. That this really is bone, that is, dense extracellular collagen into which mineral is transported, can be substantiated in a number of ways, a straightforward being to embed and section the bone. The extracellular collagen matrix can then be 

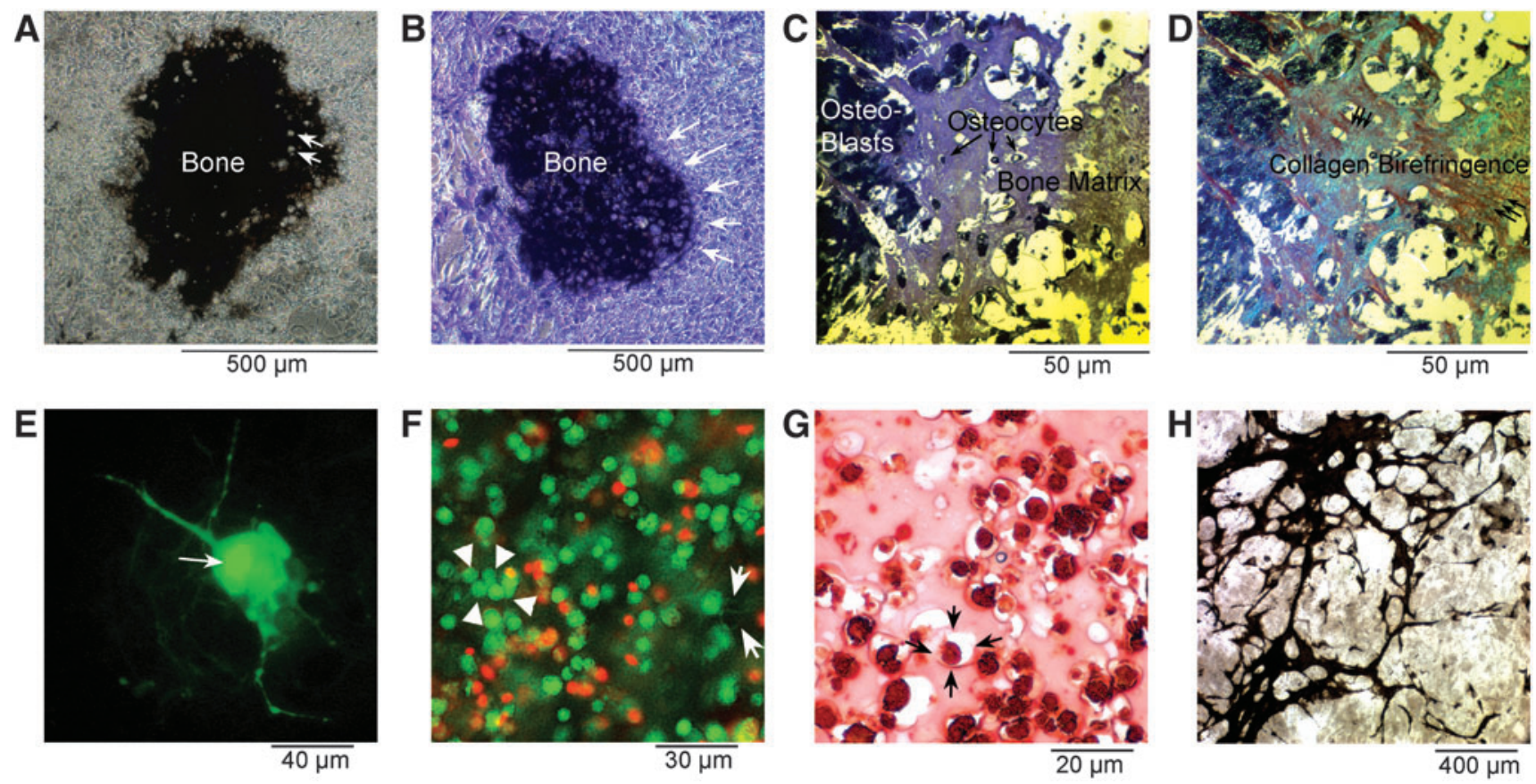

FIG. 3. Characteristics of osteoblast cultures with and without hydrogel support. (A) In high-quality osteoblast cultures in a permissive medium without supporting gels, expanding dome-like mineralized bone matrix is produced. This is an unpublished photograph of a preparation made as reported. ${ }^{21}$ Matrix produced by human osteoblasts 3 weeks in a medium with glycerol-2phosphate and ascorbic acid. The matrix is silver stained (von Kossa) and shows regions of dense extracellular matrix with lucencies corresponding to cells incorporated in matrix (arrows). The culture is shown in phase to emphasize the dense osteoblast layer surrounding the bone. A low-power field, $0.8 \mathrm{~mm}$ across. (B) Alkaline phosphatase activity in a duplicate well of the same preparation as (A). ${ }^{21}$ Where extracellular mineralized matrix occurs (matrix), alkaline phosphatase in surface cells is strongly active and appears black by $\alpha$-naphthol phosphate-fast blue RR staining. In nonmineralizing areas, cells expressing alkaline phosphatase are outlined by blue; the enzyme is membrane bound. This culture is also shown in phase, and the line of osteoblast surrounding the bone nodule is clearly seen (arrows). (C) A culture similar to (B) embedded in epon (epoxy) and cut as a $1 \mu \mathrm{m}$ section, stained with methylene blue to demonstrate the extracellular matrix containing osteocytes. Dense osteoblasts line the left side of the section. (D) The same section as (C) photographed with crossed polarizers to demonstrate collagen fibrils by their birefringence, which is blue-green or red depending on the orientation. The orientation of fibrils, as in living bone, is in layers oriented at right angles. (E) A culture of human osteoblasts on tissue culture plastic where one cell (arrow) was injected with lucifer yellow, a low-molecular-weight fluor that is small enough to pass through gap junctions. Note that cell processes and adjacent cells are labeled. From published work, ${ }^{93}$ used with permission. (F) A culture of human mesenchymal stem cells in the osteoblast differentiation medium in $1.5 \%$ hydrogel polyethylene glycol diacrylate photo-crosslinked. The culture is stained with calcein acetoxymethyl ester (nuclei bright green, cytoplasm green) and propidium iodide (dead nuclei red). Intercellular connections are seen. A few are indicated by arrows; note similarity to processes in (D); over $80 \%$ of the cells are alive 12 days after encapsulation. In addition to intercellular connections, groups of closely apposed cells occur (arrowheads). (G) Murine MSCs encapsulated in 10\% gelatin hydrogel in the bone differentiation medium for 7 days. Shrunken dead cells that have accumulated calcium (dystrophic calcification) by alizarin red staining; there is no extracellular matrix (see Fig. 3D). The gelatin capsule around one cell is indicated (arrows). This is intracelluar calcium, extracellular calcium phosphate crystals also stain and are not bone. ${ }^{52}(\mathbf{H})$ A von Kossa stain of MSC from ClC3-knockout animals in the bone differentiation medium, without hydrogel supports, 21 days. An unpublished photograph from the published study. ${ }^{5}$ Note the trabecular pattern of the mineralized matrix, which contains dense collagen (not illustrated). MSC, mesenchymal stem cells.

demonstrated directly by its birefringence (Fig. 3C, D), exactly as it is used for thin sections ex vivo to demonstrate woven or lamellar bone. ${ }^{95}$ A disadvantage of polarized light birefringence is that it will not work on most types of plastic; glass slides, used here, are needed. It may also be useful to demonstrate the type I collagen directly, although this is rarely done.

\section{Permissive conditions; inclusion of glucocorticoids often is counter-productive}

Bone differentiation is fostered in vitro from mesenchymal stem cells using permissive conditions, including ascorbic acid and a phosphatase substrate, usually glycerol-2-phosphate ( $\beta$ glycerol phosphate). ${ }^{96}$ Natural substrates, pyrophosphate and nucleotide phosphates, ${ }^{97}$ tend not to work well in vitro; particularly, pyrophosphate is an inhibitor when added to the extracellular space, despite that, osteoblasts secrete it into the phosphatase-rich mineral formation space. High concentrations of ATP can inhibit mineralization; in its natural role, it is rapidly degraded and ATP does not accumulate; adenosine itself promotes osteoblast differentiation. ${ }^{98}$ From the $1990 \mathrm{~s}$, glucocorticoids have often been included. ${ }^{96}$ Glucocorticoids promote osteoblast survival ${ }^{76}$ and permit differentiation, ${ }^{96}$ but they greatly reduce proliferation. ${ }^{10}$ Thus, glucocorticoids might speed alkaline phosphatase expression, but bone matrix 
formation is suppressed, often severely, because cell division is needed to enlarge bone-forming units.

Furthermore, solutions with $\sim 10 \mathrm{mM}$ glycerol-2-phosphate and $1.5 \mathrm{mM}$ calcium, with high alkaline phosphatase activity,

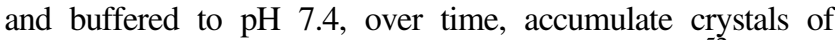
acellular and organic matrix-free calcium phosphates. ${ }^{52}$ Neither von Kossa nor alizarin red binding to crystals indicate bone. Bone is delimited by cells and requires that mineral is deposited in the dense collagen matrix. Bone forms only in dense cell cultures, and it is important not to mistake staining with alizarin red or silver of dead cells (dystrophic calcification) for bone.

The bone nodules shown in Figure 3A-D were produced without glucocorticoids; we find that with either murine or human osteoblasts, more consistent bone is formed without glucocorticoids. Murine cells are resistant to glucocorticoids; so reduction of bone synthesis in this case tends to be less. Earlier, highly successful bovine in vitro bone differentiation did not use glucocorticoids. ${ }^{99}$ It became fashionable in the $1990 \mathrm{~s}$ to add glucocorticoids to study osteoblast marker expression, ${ }^{96}$ but glucocorticoids do not improve bone matrix production. $^{10}$

\section{Osteoblast differentiation requires GDFs}

These are largely produced by the cultures themselves (Table 1), but the order of differentiation and intermediate stages are not known. So one waits for spontaneous bone formation. Even in the rare progressive disease, fibrodysplasia ossificans progressiva, ${ }^{30}$ where the body slowly is encased in ectopic bone with an activating mutation in ACVR1 (Table 1), ectopic bone formation occurs when minor trauma disturbs the metastable condition of mesenchymal stem cells that bear the constitutively active BMP receptor. What factors the minor trauma induces, probably quite locally, are not known at this point.

\section{Bone is a tissue, composed of multiple cell types}

Cells at many different stages of development occur in mesenchymal stem cell cultures. In consequence many more cytokines occur, than is expected. This includes high amounts of TGF $\beta$ (Table 1), and in keeping with this cartilage-associated agent, the cultures make aggrecan (not shown; it is the protein core of a key proteoglycan). Demonstration of cartilage in vitro, generally fibrocartilage, requires pellet cultures, but may be accomplished on membranes with special atmosphere. ${ }^{100}$ This is relevant because when bone nodules form, they may do so adjacent to cells with, at least, partial cartilage characteristics, ${ }^{101}$ as occurs in vivo in callus. Careful examination of cultures with nodular bone also often discloses tubular structures with capillary antigen markers. ${ }^{15}$ This is expected; mesenchymal stem cells undergo vascular differentiation with VEGF. ${ }^{102}$

\section{Critical Evaluation of Suitable Conditions for Bone Formation In Vitro}

Murine cells usually differentiate to form bone in about 14 21 days. Human cells take longer to produce mineralized matrix, often 28 days. Unconstrained osteoblasts differentiating in vitro have many intercellular connections, including abundant connexin 43 gap junctions. ${ }^{93}$ In consequence, injection of the lowMW fluor lucifer yellow into one osteoblast labels the cell, cell processes, and many adjacent cells (Fig. 3E). This is important in making $3 \mathrm{D}$ cultures that require hydrogels to prevent cells set- tling out of the culture. A practical method to determine if a hydrogel is porous enough to allow cell processes to permeate the gel is to label it with calcein acetoxymethyl ester, which allows the cell-cell communication to be seen (Fig. 3F). If cells are constrained from making cell-cell contacts, they make no bone and also die (Fig. 3G). The cells undergo anoikis, a form of apoptosis affecting anchorage-dependent cells. This culture (Fig. 3G) is also an example of alizarin red staining that is not bone: the dead cells have undergone dystrophic calcification, which should not be mistaken for extracellular matrix. In addition to cell-cell attachments, proteins that allow integrin binding to cells, including intact collagen, may suppress apoptosis. ${ }^{103}$ Fine granular precipitates of calcium phosphates, not bound by or including cells, are not bone. ${ }^{52}$

\section{Improving Bone Quality In Vitro}

Frequently, especially in hydrogel-supported cultures, PCR is required to detect increases in bone markers; increases relative to MSC precursors may be less than 10-fold. In the best dense unsupported osteoblast differentiation, key osteoblast proteins increase $\sim 200-300$-fold. ${ }^{22}$

Improving quantitative bone differentiation may involve providing surfaces to nucleate osteon formation, increased cell density, management of nutrient flow, and other factors. The normal osteon forms where existing extracellular matrix, cartilage, or bone is eroded by osteoclasts. A cement line is secreted at this site (Fig. 1D). The site contains residual material secreted by osteoclasts, including tartrate-resistant acid phosphatase. There is direct evidence that tartrate resistant acid phosphatase is osteoinductive, ${ }^{104}$ but the utility of making conditioned artificial calcified templates for osteoblast attachment has not been investigated fully. Many resorbable substrates have been tested, often with added growth factors. ${ }^{105}$ Other advances include our discovery that $\mathrm{ClC} 3$ knockout cells make trabecular bone in vitro (Fig. $3 \mathrm{H}) .{ }^{5}$ If this mouse phenotype translates into human cells and can be scaled, it has potential. Important considerations in further work include accounting for growth factor production by implanted cells (Table 1), and the natural expression of growth factors generally is as membrane-tethered proteins on presenting cells adjacent to the responding cells. Calcium phosphate ceramics as bone-inducing agents show results often comparable to bone grafts. ${ }^{106,107}$ In bioreactors, results often lag, often reflecting limitations in cell density.

Cultures of MSCs that form bone nodules can induce capillary formation. ${ }^{15}$ The degree of feedback on osteoblasts from vascular cells around bone is unknown. Related considerations are hypoxia-induced factors (HIF). HIF $1 \alpha$ is highly expressed in osteoblasts in vitro even at high oxygen tension. Many studies have shown that HIF1 $\alpha$ negatively effects bone matrix production, while fostering cell survival. $^{108-110}$ The pathway is complex, and feeds back in production of VEGF and BMP production. ${ }^{111,112}$

In cell cultures, many osteoblast precursors form osteocytelike connections (Fig. 3E); how this affects further cell differentiation is uncertain, but there definitely is high production of sclerostin in human osteoblast cultures (Table 1), and sclerostin inhibits mineralized bone formation. ${ }^{113,114}$ Potential methods for limiting effects in vitro include blocking antibodies, ${ }^{114}$ or knockdown of sclerostin in mesenchymal stem cells used for bone differentiation. 


\section{Conclusion}

New understanding of bone physiology, including the role of ion transporters in bone formation, will make it possible to refine models for control of bone formation, in vivo and in vitro. Management of bone in vivo will increasingly account for factors including ACTH support of bone vasculature. It is likely that complete success of mesenchymal stem cell differentiation in vitro for bone transplant will require osteoblast binding and differentiation sites, in part, reflecting the transport processes that push mineralization of dense bone matrix in living bone (Fig. 2C). Sophisticated models that account for production of inhibitory cytokines, such as sclerostin, are needed. Production of trabecular bone in vitro may be important. Trabecular bone has a high surface to volume ratio that may facilitate revascularization and remodeling.

\section{Acknowledgments}

Supported, in part, by the Department of Veterans Affairs grant I01BX002490 and by the National Institutes of Health grants AR065407-01, U54GM104942, and HL125076.

\section{Disclosure Statement}

No competing financial interests exist.

\section{References}

1. Blair, H.C., Zaidi, M., Huang, C.L., and Sun, L. The developmental basis of skeletal cell differentiation and the molecular basis of major skeletal defects. Biol Rev Camb Philos Soc 83, 401, 2008.

2. Danišovič, L., Varga, I., and Polák, S. Growth factors and chondrogenic differentiation of mesenchymal stem cells. Tissue Cell 44, 69, 2012.

3. Fujisawa, R., and Tamura, M. Acidic bone matrix proteins and their roles in calcification. Front Biosci 17, 1891, 2012.

4. Reznikov, N., Shahar, R., and Weiner, S. Bone hierarchical structure in three dimensions. Acta Biomater 10, 3815, 2014.

5. Larrouture, Q.C., Nelson, D.J., Robinson, L.J., Liu, L., Tourkova, I., Schlesinger, P.H., and Blair, H.C. Chloridehydrogen antiporters $\mathrm{ClC}-3$ and $\mathrm{ClC}-5$ drive osteoblast mineralization and regulate fine-structure bone patterning in vitro. Physiol Rep 3.pii, e12607, 2015.

6. Gadaleta, S.J., Paschalis, E.P., Betts, F., Mendelsohn, R., and Boskey, A.L. Fourier transform infrared spectroscopy of the solution-mediated conversion of amorphous calcium phosphate to hydroxyapatite: new correlations between X-ray diffraction and infrared data. Calcif Tissue Int 58, 9, 1996.

7. Shapiro, I.M., Landis, W.J., and Risbud, M.V. Matrix vesicles: are they anchored exosomes? Bone 79, 29, 2015.

8. Canalis, E., McCarthy, T., and Centrella, M. Growth factors and the regulation of bone remodeling. J Clin Invest $\mathbf{8 1}, 277,1988$.

9. Benisch, P., Schilling, T., Klein-Hitpass, L., Frey, S.P., Seefried, L., Raaijmakers, N., Krug, M., Regensburger, M., Zeck, S., Schinke, T., Amling, M., Ebert, R., and Jakob, F. The transcriptional profile of mesenchymal stem cell populations in primary osteoporosis is distinct and shows overexpression of osteogenic inhibitors. PLoS One 7, e45142, 2012.
10. Chang, P.L., Blair, H.C., Zhao, X., Chien, Y.W., Chen, D., Tilden, A.B., Chang, Z., Cao, X., Faye-Petersen, O.M., and Hicks, P. Comparison of fetal and adult marrow stromal cells in osteogenesis with and without glucocorticoids. Connect Tissue Res 47, 67, 2006.

11. Komarova, S.V., Ataullakhanov, F.I., and Globus, R.K. Bioenergetics and mitochondrial transmembrane potential during differentiation of cultured osteoblasts. Am J Physiol Cell Physiol 279, C1220, 2000.

12. Ahn, S.H., Park, S.Y., Baek, J.E., Lee, S.Y., Baek, W.Y., Lee, S.Y., Lee, Y.S., Yoo, H.J., Kim, H., Lee, S.H., Im, D.S., Lee, S.K., Kim, B.J., and Koh, J.M. Free fatty acid receptor 4 (GPR120) stimulates bone formation and suppresses bone resorption in the presence of elevated n-3 fatty acid levels. Endocrinology 157, 2621, 2016.

13. Blair, H.C., Kalyvioti, E., Papachristou, N.I., Tourkova, I.L., Syggelos, S.A., Deligianni, D., Orkoula, M.G., Kontoyannis, C.G., Karavia, E.A., Kypreos, K.E., and Papachristou, D.J. Apolipoprotein A-1 regulates osteoblast and lipoblast precursor cells in mice. Lab Invest 96, 763, 2016.

14. Tourkova, I.L., Witt, M.R., Li, L., Larrouture, Q., Liu, L., Luo, J., Robinson, L.J., and Blair, H.C. Follicle stimulating hormone receptor in mesenchymal stem cells integrates effects of glycoprotein reproductive hormones. Ann N Y Acad Sci 1335, 100, 2015.

15. Zaidi, M., Sun, L., Robinson, L.J., Tourkova, I.L., Liu, L., Wang, Y., Zhu, L.L., Liu, X., Li, J., Peng, Y., Yang, G., Shi, X., Levine, A., Iqbal, J., Yaroslavskiy, B.B., Isales, C., and Blair, H.C. ACTH protects against glucocorticoidinduced osteonecrosis of bone. Proc Natl Acad Sci U S A 107, 8782, 2010.

16. Eberhardt, A.W., Yeager-Jones, A., and Blair, H.C. Regional trabecular bone matrix degeneration and osteocyte death in femora of glucocorticoid-treated rabbits. Endocrinology 142, 1333, 2001.

17. Siggelkow, H., Eidner, T., Lehmann, G., Viereck, V., Raddatz, D., Munzel, U., Hein, G., and Hüfner, M. Cytokines, osteoprotegerin, and RANKL in vitro and histomorphometric indices of bone turnover in patients with different bone diseases. J Bone Miner Res 18, 529, 2003.

18. Twine, N.A., Chen, L., Pang, C.N., Wilkins, M.R., and Kassem, M. Identification of differentiation-stage specific markers that define the ex vivo osteoblastic phenotype. Bone 67, 23, 2014.

19. Wei, J., and Karsenty, G. An overview of the metabolic functions of osteocalcin. Rev Endocr Metab Disord 16, 93, 2015.

20. Xu, S.J., Qiu, Z.Y., Wu, J.J., Kong, X.D., Weng, X.S., Cui, F.Z., and Wang, X.M. Osteogenic differentiation gene expression profiling of hMSCs on hydroxyapatite and mineralized collagen. Tissue Eng Part A 22, 170, 2016.

21. Liu, L., Schlesinger, P.H., Slack, N.M., Friedman, P.A., and Blair, H.C. High capacity $\mathrm{Na}+\mathrm{H}+$ exchange activity in mineralizing osteoblasts. J Cell Physiol 226, 1702, 2011.

22. Liu, L., Alonso, V., Guo, L., Tourkova, I., Henderson, S.E., Almarza, A.J., Friedman, P.A., and Blair, H.C. Na+l $\mathrm{H}+$ exchanger regulatory factor 1 (NHERF1) directly regulates osteogenesis. J Biol Chem 287, 43312, 2012.

23. Wang, B., Yang, Y., Liu, L., Blair, H.C., and Friedman, P.A. NHERF1 regulation of PTH-dependent bimodal Pi transport in osteoblasts. Bone 52, 268, 2013.

24. Delgado-Calle, J., and Bellido, T. Osteocytes and skeletal pathophysiology. Curr Mol Biol Rep 1, 157, 2015. 
25. Williams, B.O., and Insogna, K.L. Where Wnts went: the exploding field of Lrp5 and Lrp6 signaling in bone. J Bone Miner Res 24, 171, 2009.

26. Schmid, P., Cox, D., Bilbe, G., Maier, R., and McMaster G.K. Differential expression of TGFbeta1, beta2 and beta3 genes during mouse embryogenesis. Development 111, 117, 1991.

27. Chung, W.S., Shin, C.H., and Stainier, D.Y. Bmp2 signaling regulates the hepatic versus pancreatic fate decision. Dev Cell 15, 738, 2008.

28. Ono, I., Akasaka, Y., Kamiya, T., Sato, M., Kobune, M., Hamada, H., and Yamashita, T. De novo follicular regeneration of the skin by wingless int 3 and bone morphogenetic protein 2 genes introduced into dermal fibroblasts and fibroblast growth factor-2 protein. Wound Repair Regen 17, 436, 2009.

29. Danesh, S.M., Villasenor, A., Chong, D., Soukup, C., and Cleaver, O. BMP and BMP receptor expression during murine organogenesis. Gene Expr Patterns 9, 255, 2009.

30. Pignolo, R.J., Shore, E.M., and Kaplan, F.S. Fibrodysplasia ossificans progressiva: diagnosis, management, and therapeutic horizons. Pediatr Endocrinol Rev 10 Suppl 2, 437, 2013.

31. Filvaroff, E., Erlebacher, A., Ye, J., Gitelman, S.E., Lotz, J., Heillman, M., and Derynck, R. Inhibition of TGF-beta receptor signaling in osteoblasts leads to decreased bone remodeling and increased trabecular bone mass. Development 126, 4267, 1999.

32. Edgar, C.M., Chakravarthy, V., Barnes, G., Kakar, S., Gerstenfeld, L.C., and Einhorn, T.A. Autogenous regulation of a network of bone morphogenetic proteins (BMPs) mediates the osteogenic differentiation in murine marrow stromal cells. Bone 40, 1389, 2007.

33. Djouad, F., Bony, C., Häupl, T., Uzé, G., Lahlou, N., Louis-Plence, P., Apparailly, F., Canovas, F., Rème, T., Sany, J., Jorgensen, C., and Noël, D. Transcriptional profiles discriminate bone marrow-derived and synoviumderived mesenchymal stem cells. Arthritis Res Ther 7, R1304, 2005.

34. Liu, L., Wang, Y., Fan, H., Zhao, X., Liu, D., Hu, Y., Kidd, A.R., 3rd, Bao, J., and Hou, Y. MicroRNA-181a regulates local immune balance by inhibiting proliferation and immunosuppressive properties of mesenchymal stem cells. Stem Cells 30, 1756, 2012.

35. Biver, E., Soubrier, A.S., Thouverey, C., Cortet, B., Broux, O., Caverzasio, J., and Hardouin, P. Fibroblast growth factor 2 inhibits up-regulation of bone morphogenic proteins and their receptors during osteoblastic differentiation of human mesenchymal stem cells. Biochem Biophys Res Commun 427, 737, 2012.

36. Culbert, A.L., Chakkalakal, S.A., Theosmy, E.G., Brennan, T.A., Kaplan, F.S., and Shore, E.M. Alk2 regulates early chondrogenic fate in fibrodysplasia ossificans progressiva heterotopic endochondral ossification. Stem Cells 32, 1289, 2014.

37. Golub, E.E., Harrison, G., Taylor, A.G., Camper, S., and Shapiro, I.M. The role of alkaline phosphatase in cartilage mineralization. Bone Miner 17, 273, 1992.

38. Garnero, P., and Delmas, P.D. Biochemical markers of bone turnover. Applications for osteoporosis. Endocrinol Metab Clin North Am 27, 303, 1998.

39. Young, M.F., Kerr, J.M., Ibaraki, K., Heegaard, A.M., and Robey, P.G. Structure, expression, and regulation of the major noncollagenous matrix proteins of bone. Clin Orthop Relat Res 281, 275, 1992.

40. Burr, D.B., Schaffler, M.B., and Frederickson, R.G. Composition of the cement line and its possible mechanical role as a local interface in human compact bone. $\mathrm{J}$ Biomech 21, 939, 1988.

41. Batra, N., Kar, R., and Jiang, J.X. Gap junctions and hemichannels in signal transmission, function and development of bone. Biochim Biophys Acta 1818, 1909, 2012.

42. Shapiro, F. Variable conformation of GAP junctions linking bone cells: a transmission electron microscopic study of linear, stacked linear, curvilinear, oval, and annular junctions. Calcif Tissue Int 61, 285, 1997.

43. Yellowley, C.E., Li, Z., Zhou, Z., Jacobs, C.R., and Donahue, H.J. Functional gap junctions between osteocytic and osteoblastic cells. J Bone Miner Res 15, 209, 2000.

44. Cretin, A. Contribution histochimique a l'etude de la construction et de la destruction osseuse [Histochemical contribution to the study of bone construction and destruction]. La Presse Med 59, 1240, 1951.

45. Blair, H.C., Kahn, A.J., Crouch, E.C., Jeffrey, J.J., and Teitelbaum, S.L. Isolated osteoclasts resorb the organic and inorganic components of bone. J Cell Biol 102, 1164, 1986.

46. Frost, H.M. Relation between bone tissue and cell population dynamics, histology and tetracycline labeling. Clin Orthop Relat Res 49, 65, 1966.

47. Kozloff, K.M., Weissleder, R., and Mahmood, U. Noninvasive optical detection of bone mineral. J Bone Miner Res 22, 1208, 2007.

48. Neuman, W.F., and Neuman, M.W. The Chemical Dynamics of Bone Mineral. Chicago: The University of Chicago Press, 1958, p. 209.

49. Blair, H.C., Teitelbaum, S.L., Tan, H.L., Koziol, C.M., and Schlesinger, P.H. Passive chloride permeability charge coupled to H+-ATPase of avian osteoclast ruffled membrane. Am J Physiol 260, C1315, 1991.

50. Green, J., Yamaguchi, D.T., Kleeman, C.R., and Muallem, $\mathrm{S}$. Cytosolic $\mathrm{pH}$ regulation in osteoblasts. Interaction of $\mathrm{Na}^{+}$and $\mathrm{H}^{+}$with the extracellular and intracellular faces of the Na+/H+ exchanger. J Gen Physiol 92, 239, 1988.

51. Redhead, C.R., and Baker, P.F. Control of intracellular pH in rat calvarial osteoblasts: coexistence of both chloridebicarbonate and sodium-hydrogen exchange. Calcif Tissue Int 42, 237, 1988.

52. Bonewald, L.F., Harris, S.E., Rosser, J., Dallas, M.R., Dallas, S.L., Camacho, N.P., Boyan, B., and Boskey, A. von Kossa staining alone is not sufficient to confirm that mineralization in vitro represents bone formation. Calcif Tissue Int 72, 537, 2003.

53. Fedde, K.N., Blair, L., Silverstein, J., Coburn, S.P., Ryan, L.M., Weinstein, R.S., Waymire, K., Narisawa, S., Millán, J.L., MacGregor, G.R., and Whyte, M.P. Alkaline phosphatase knock-out mice recapitulate the metabolic and skeletal defects of infantile hypophosphatasia. J Bone Miner Res 14, 2015, 1999.

54. Blair, H.C., Robinson, L.J., Huang, C.L., Sun, L., Friedman, P.A., Schlesinger, P.H., and Zaidi, M. Calcium and bone disease. Biofactors 37, 159, 2011.

55. Yadav, M.C., Simão, A.M., Narisawa, S., Huesa, C., McKee, M.D., Farquharson, C., and Millán, J.L. Loss of skeletal mineralization by the simultaneous ablation of PHOSPHO1 and alkaline phosphatase function: a unified 
model of the mechanisms of initiation of skeletal calcification. J Bone Miner Res 26, 286, 2011.

56. Polewski, M.D., Johnson, K.A., Foster, M., Millán, J.L., and Terkeltaub, R. Inorganic pyrophosphatase induces type I collagen in osteoblasts. Bone 46, 81, 2010.

57. Mobasheri, A., Wray, S., and Marples, D. Distribution of AQP2 and AQP3 water channels in human tissue microarrays. J Mol Histol 36, 1, 2005.

58. Li, X., Dong, X., Zheng, S., and Xiao, J. Expression and localization of TASK-1, -2 and -3 channels in MG63 human osteoblast-like cells. Oncol Lett 5, 865, 2013.

59. Arana-Chavez, V.E., Soares, A.M., and Katchburian, E. Junctions between early developing osteoblasts of rat calvaria as revealed by freeze-fracture and ultrathin section electron microscopy. Arch Histol Cytol 58, 285, 1995.

60. Wongdee, K., Pandaranandaka, J., Teerapornpuntakit, J., Tudpor, K., Thongbunchoo, J., Thongon, N., Jantarajit, W., Krishnamra, N., and Charoenphandhu, N. Osteoblasts express claudins and tight junction-associated proteins. Histochem Cell Biol 130, 79, 2008.

61. Hatakeyama, N., Kojima, T., Iba, K., Murata, M., Thi, M.M., Spray, D.C., Osanai, M., Chiba, H., Ishiai, S., Yamashita, T., and Sawada, N. IGF-I regulates tightjunction protein claudin-1 during differentiation of osteoblast-like MC3T3-E1 cells via a MAP-kinase pathway. Cell Tissue Res 334, 243, 2008.

62. Alshbool, F.Z., and Mohan, S. Differential expression of claudin family members during osteoblast and osteoclast differentiation: Cldn-1 is a novel positive regulator of osteoblastogenesis. PLoS One 9, e114357, 2014.

63. Alshbool, F.Z., and Mohan, S. Emerging multifunctional roles of Claudin tight junction proteins in bone. Endocrinology 155, 2363, 2014.

64. Monjo, M., Rubert, M., Ellingsen, J.E., and Lyngstadaas, S.P. Rosuvastatin promotes osteoblast differentiation and regulates SLCO1A1 transporter gene expression in MC3T3-E1 cells. Cell Physiol Biochem 26, 647, 2010.

65. Comes, C.M., van Paassen, H., Romeo, S., Welling, M.M., Feitsma, R.I., Abrunhosa, A.J., Botelho, M.F., Hogendoorn, P.C., Pauwels, E., and Cleton- Jansen, A.M. Multidrug resistance mediated by $\mathrm{ABC}$ transporters in osteosarcoma cell lines: mRNA analysis and functional radiotracer studies. Nucl Med Biol 33, 831, 2006.

66. Morris, D.C., Masuhara, K., Takaoka, K., Ono, K., and Anderson, H.C. Immunolocalization of alkaline phosphatase in osteoblasts and matrix vesicles of human fetal bone. Bone Miner 19, 287, 1992.

67. Lakkaraju, A., and Rodriguez-Boulan, E. Itinerant exosomes: emerging roles in cell and tissue polarity. Trends Cell Biol 18, 199, 2008.

68. Anderson, H.C. Matrix vesicles and calcification. Curr Rheumatol Rep 5, 222, 2003.

69. Chapman, J.A. The staining pattern of collagen fibrils. I. An analysis of electron micrographs. Connect Tissue Res 2, 137, 1974.

70. Chapman, J.A., and Hardcastle, R.A. The staining pattern of collagen fibrils. II. A comparison with patterns computer-generated from the amino acid sequence. Connect Tissue Res 2, 151, 1974.

71. Silver, F.H., and Landis, W.J. Deposition of apatite in mineralizing vertebrate extracellular matrices: a model of possible nucleation sites on type I collagen. Connect Tissue Res 52, 242, 2011.
72. Xu, Z., Yang, Y., Zhao, W., Wang, Z., Landis, W.J., Cui, Q., and Sahai, N. Molecular mechanisms for intrafibrillar collagen mineralization in skeletal tissues. Biomaterials 39, 59, 2015.

73. Marelli, B., Ghezzi, C.E., Zhang, Y.L., Rouiller, I., Barralet, J.E., and Nazhat, S.N. Fibril formation pH controls intrafibrillar collagen biomineralization in vitro and in vivo. Biomaterials 37, 252, 2015.

74. Sundquist, K., Lakkakorpi, P., Wallmark, B., and Väänänen, K. Inhibition of osteoclast proton transport by bafilomycin A1 abolishes bone resorption. Biochem Biophys Res Commun 168, 309, 1990.

75. Abe, E., Marians, R.C., Yu, W., Wu, X.B., Ando, T., Li, Y., Iqbal, J., Eldeiry, L., Rajendren, G., Blair, H.C., Davies, T.F., and Zaidi, M. TSH is a negative regulator of skeletal remodeling. Cell 115, 151, 2003.

76. Pereira, R.M., Delany, A.M., and Canalis, E. Cortisol inhibits the differentiation and apoptosis of osteoblasts in culture. Bone 28, 484, 2001.

77. Riggs, B.L., Khosla, S., and Melton, L.J., 3rd. Sex steroids and the construction and conservation of the adult skeleton. Endocr Rev 23, 279, 2002.

78. Bassett, J.H., and Williams, G.R. The skeletal phenotypes of TRalpha and TRbeta mutant mice. J Mol Endocrinol 42, 269, 2009.

79. Jules, J., Yang, S., Chen, W., and Li, Y.P. Role of regulators of $\mathrm{G}$ protein signaling proteins in bone physiology and pathophysiology. Prog Mol Biol Transl Sci 133, 47, 2015.

80. Chim, S.M., Tickner, J., Chow, S.T., Kuek, V., Guo, B., Zhang, G., Rosen, V., Erber, W., and Xu, J. Angiogenic factors in bone local environment. Cytokine Growth Factor Rev 24, 297, 2013.

81. Gerber, H.P., Vu, T.H., Ryan, A.M., Kowalski, J., Werb, Z., and Ferrara, N. VEGF couples hypertrophic cartilage remodeling, ossification and angiogenesis during endochondral bone formation. Nat Med 5, 623, 1999.

82. Maeda, Y., Nakamura, E., Nguyen, M.T., Suva, L.J., Swain, F.L., Razzaque, M.S., Mackem, S., and Lanske, B. Indian Hedgehog produced by postnatal chondrocytes is essential for maintaining a growth plate and trabecular bone. Proc Natl Acad Sci U S A 104, 6382, 2007.

83. Canalis, E. Wnt signalling in osteoporosis: mechanisms and novel therapeutic approaches. Nat Rev Endocrinol 9, 575, 2013.

84. Beederman, M., Lamplot, J.D., Nan, G., Wang, J., Liu, X., Yin, L., Li, R., Shui, W., Zhang, H., Kim, S.H., Zhang, W., Zhang, J., Kong, Y., Denduluri, S., Rogers, M.R., Pratt, A., Haydon, R.C., Luu, H.H., Angeles, J., Shi, L.L., and He, T.C. BMP signaling in mesenchymal stem cell differentiation and bone formation. J Biomed Sci Eng 6, 32, 2013.

85. Storm, E.E., and Kingsley, D.M. GDF5 coordinates bone and joint formation during digit development. Dev Biol 209, 11, 1999.

86. Rosen, V. BMP and BMP inhibitors in bone. Ann N Y Acad Sci 1068, 19, 2006.

87. Tylzanowski, P., Mebis, L., and Luyten, F.P. The Noggin null mouse phenotype is strain dependent and haploinsufficiency leads to skeletal defects. Dev Dyn 235, 1599, 2006.

88. Karuppaiah, K., Yu, K., Lim, J., Chen, J., Smith, C., Long, F., and Ornitz, D.M. FGF signaling in the osteoprogenitor lineage non-autonomously regulates postnatal chondrocyte 
proliferation and skeletal growth. Development 143, 1811, 2016.

89. Marie, P.J. Fibroblast growth factor signaling controlling bone formation: an update. Gene 498, 1, 2012.

90. Harmer, N.J. Insights into the role of heparan sulphate in fibroblast growth factor signalling. Biochem Soc Trans 34(Pt 3), 442, 2006.

91. Lederer, E. Regulation of serum phosphate. J Physiol 592, 3985, 2014.

92. Silva, B.C., Costa, A.G., Cusano, N.E., Kousteni, S., and Bilezikian, J.P. Catabolic and anabolic actions of parathyroid hormone on the skeleton. J Endocrinol Invest 34, $801,2011$.

93. Sharrow, A.C., Li, Y., Micsenyi, A., Griswold, R.D., Wells, A., Monga, S.S., and Blair, H.C. Modulation of osteoblast gap junction connectivity by serum, TNFalpha, and TRAIL. Exp Cell Res 314, 297, 2008.

94. Bu, R., Borysenko, C.W., Li, Y., Cao, L., Sabokbar, A., and Blair, H.C. Expression and function of TNF-family proteins and receptors in human osteoblasts. Bone 33, 760, 2003.

95. Robinson, L.J., Mancarella, S., Songsawad, D., Tourkova, I.L., Barnett, J.B., Gill, D.L., Soboloff, J., and Blair, H.C. Gene disruption of the calcium channel Orail results in inhibition of osteoclast and osteoblast differentiation and impairs skeletal development. Lab Invest 92, 1071, 2012.

96. Pittenger, M.F., Mackay, A.M., Beck, S.C., Jaiswal, R.K., Douglas, R., Mosca, J.D., Moorman, M.A., Simonetti, D.W., Craig, S., and Marshak, D.R. Multilineage potential of adult human mesenchymal stem cells. Science 284, 143, 1999.

97. Nakano, Y., Addison, W.N., and Kaartinen, M.T. ATPmediated mineralization of MC3T3-E1 osteoblast cultures. Bone 41, 549, 2007.

98. Gharibi, B., Abraham, A.A., Ham, J., and Evans, B.A. Adenosine receptor subtype expression and activation influence the differentiation of mesenchymal stem cells to osteoblasts and adipocytes. J Bone Miner Res 26, 2112, 2011.

99. Whitson, S.W., Harrison, W., Dunlap, M.K., Bowers, D.E., Jr., Fisher, L.W., Robey, P.G., and Termine, J.D. Fetal bovine bone cells synthesize bone-specific matrix proteins. J Cell Biol 99, 607, 1984.

100. Mayer-Wagner, S., Schiergens, T.S., Sievers, B., Docheva, D., Schieker, M., Betz, O.B., Jansson, V., and Müller, P.E. Membrane-based cultures generate scaffoldfree neocartilage in vitro: influence of growth factors. Tissue Eng Part A 16, 513, 2010.

101. zur Nieden, N.I., Kempka, G., Rancourt, D.E., and Ahr, H.J. Induction of chondro-, osteo- and adipogenesis in embryonic stem cells by bone morphogenetic protein-2: effect of cofactors on differentiating lineages. BMC Dev Biol 5, 1, 2005.

102. Arutyunyan, I., Fatkhudinov, T., Kananykhina, E., Usman, N., Elchaninov, A., Makarov, A., Bolshakova, G., Goldshtein, D., and Sukhikh, G. Role of VEGF-A in angiogenesis promoted by umbilical cord-derived mesenchymal stromal/stem cells: in vitro study. Stem Cell Res Ther 7, 46, 2016.

103. Alcaide, M., Serrano, M.C., Roman, J., Cabañas, M.V., Peña, J., Sánchez-Zapardiel, E., Vallet-Regí, M., and Portolés, M.T. Suppression of anoikis by collagen coating of interconnected macroporous nanometric carbonated hydroxyapatite/agarose scaffolds. J Biomed Mater Res A 95, 793, 2010.

104. Gradin, P., Hollberg, K., Cassady, A.I., Lång, P., and Andersson, G. Transgenic overexpression of tartrate-resistant acid phosphatase is associated with induction of osteoblast gene expression and increased cortical bone mineral content and density. Cells Tissues Organs 196, 68, 2012.

105. Curry, A.S., Pensa, N.W., Barlow, A.M., and Bellis, S.L. Taking cues from the extracellular matrix to design bonemimetic regenerative scaffolds. Matrix Biol 52-54, 397, 2016.

106. Samavedi, S., Whittington, A.R., and Goldstein, A.S. Calcium phosphate ceramics in bone tissue engineering: a review of properties and their influence on cell behavior. Acta Biomater 9, 8037, 2013.

107. Wang, P., Zhao, L., Liu, J., Weir, M.D., Zhou, X., and Xu, H.H. Bone tissue engineering via nanostructured calcium phosphate biomaterials and stem cells. Bone Res 2, 14017, 2014.

108. Riddle, R.C., Leslie, J.M., Gross, T.S., and Clemens, T.L. Hypoxia-inducible factor- $1 \alpha$ protein negatively regulates load-induced bone formation. J Biol Chem 286, 44449, 2011.

109. Hsu, S.H., Chen, C.T., and Wei, Y.H. Inhibitory effects of hypoxia on metabolic switch and osteogenic differentiation of human mesenchymal stem cells. Stem Cells 31, 2779, 2013.

110. Yang, D.C., Yang, M.H., Tsai, C.C., Huang, T.F., Chen, Y.H., and Hung, S.C. Hypoxia inhibits osteogenesis in human mesenchymal stem cells through direct regulation of RUNX2 by TWIST. PLoS One 6, e23965, 2011.

111. Wang, Y., Wan, C., Deng, L., Liu, X., Cao, X., Gilbert, S.R., Bouxsein, M.L., Faugere, M.C., Guldberg, R.E., Gerstenfeld, L.C., Haase, V.H., Johnson, R.S., Schipani, E., and Clemens, T.L. The hypoxia-inducible factor-alpha pathway couples angiogenesis to osteogenesis during skeletal development. J Clin Invest 117, 1616, 2007.

112. Tseng, W.P., Yang, S.N., Lai, C.H., and Tang, C.H. Hypoxia induces BMP-2 expression via ILK, Akt, mTOR, and HIF-1 pathways in osteoblasts. J Cell Physiol 223, 810, 2010.

113. Atkins, G.J., Rowe, P.S., Lim, H.P., Welldon, K.J., Ormsby, R., Wijenayaka, A.R., Zelenchuk, L., Evdokiou, A., and Findlay, D.M. Sclerostin is a locally acting regulator of late-osteoblast/preosteocyte differentiation and regulates mineralization through a MEPE-ASARMdependent mechanism. J Bone Miner Res 26, 1425, 2011.

114. Ellies, D.L., Viviano, B., McCarthy, J., Rey, J.P., Itasaki, N., Saunders, S., and Krumlauf, R. Bone density ligand, Sclerostin, directly interacts with LRP5 but not LRP5G171 V to modulate Wnt activity. J Bone Miner Res 21, 1738, 2006.

Address correspondence to: Harry C. Blair, MD

Department of Pathology S705 Scaife Hall 3550 Terrace Street

Pittsburgh, PA 15261

E-mail: hcblair@pitt.edu

Received: October 18, 2016 Accepted: November 14, 2016 Online Publication Date: December 27, 2016 